\title{
A HISTORICAL APPROACH TO SYPHILIS INFECTION IN KOREA
}

\author{
POVIJESNI OSVRT NA INFEKCIJU \\ SIFILISA U KOREJI
}

\author{
Dong Hoon Shin", Hye Jin Lee ${ }^{*, * *}$, Jong Ha Hong*, Eun Jin Woo ${ }^{* * *}$, \\ Eunkyoung Shin ${ }^{* * * *}$, Yi-Suk Kim ${ }^{* * * * * *}$, Ho Chul Ki******, Eunju Lee ${ }^{* * * * * * * *}$
}

\section{SuMMARY}

From the end of the I5th century, syphilis spread worldwide, posing a serious threat to public health. Venereal syphilis has been a major research topic, not only in clinical medicine but also in paleopathology, especially because it is a disease of questionable origin and of high prevalence until the discovery of antibiotics. Syphilis in history has been studied extensively in Europe and the Americas, though less so in Asia. In this review, based on extant historical documents and available paleopathological data, we pinpoint the introduction and trace the spread of venereal syphilis in Korea to the end of the $19^{\text {th }}$ century. This review provides

\footnotetext{
Lab of Bioanthropology, Paleopathology and History of Diseases, Department of Anatomy/Institute of Forensic Science, Seoul National University College of Medicine, Seoul, South Korea.

Ministry of National Defense Agency KIA Recovery \& Identification, Seoul, South Korea.

**** Department of History, Sejong University, Seoul, South Korea.

***** Department of Social Welfare, Dankook University, Cheonan, South Korea.

****** Department of Anatomy, College of Medicine, The Catholic University of Korea, Seoul, South Korea.

******* Ancient Institute of Heritage, Jukhyun-ro 514, Hwasun-gun, South Korea.

******** Department of Internal Medicine, Asan Medical Center, University of Ulsan College of Medicine, Seoul, South Korea.

Correspondence Address: Dong Hoon Shin, Department of Anatomy/Institute of Forensic Science, Seoul National University College of Medicine, Daehak-ro 103, Chongno-gu, Seoul 110-799, South Korea.E-mail: cuteminjae@gmail.com.
} 
fundamental information that will be of great help to future research on pre-2oth century syphilis in Korea.

Keywords: Syphilis, Joseon Dynasty, Korea, origin, history, paleopathology

\section{INTRODUCTION}

Treponemal diseases are caused by the genus Treponema, a spirochete bacterium. Various treponemal diseases, including pinta caused by T. carateum, yaws by T. pallidum subsp. pertenue, and bejel or endemic syphilis by T. pallidum subsp. Endemicum, are known to infect human beings [I]. Apart from these treponemal diseases of non-venereal contact, $T$. pallidum subsp. pallidum, the most destructive subtype causing serious harm to health and sometimes leading to death, is transmitted by sexual contact (venereal syphilis) $[2,3]$. In addition to the general symptoms of sexually transmitted disease (STD) and the characteristic whole-body rash, venereal syphilis sometimes invades various internal organs, causing damage especially in the nervous (tabes dorsalis) and cardiovascular (syphilitic aortic aneurysm) systems. It sometimes involves the skeleton, leading to serious degenerative conditions such as caries sicca in the skull, saddle nose, or saber shin in the tibia. As venereal syphilis' clinical features are so variable, it is called 'the great imitator' $[2,4]$.

Until relatively recently an optimistic view had prevailed, in that venereal syphilis was seen to be readily eradicable by antimicrobial therapy, population screening, and improvements in social health care systems [5]. In fact, during the worldwide campaign against syphilis in the rg6os, its infection prevalence dropped dramatically, and endemic treponematoses (bejel, pinta and yaws) were almost eradicated $[2,6]$. However, in the rg8os, syphilis reemerged in close association with AIDS infection worldwide and economic booms in developing countries [2, 7, 8]. In 2002, 157,000 people died of syphilis, and 270,000 suffered from congenital syphilis in Africa [Io]. In this light, more attention to the prevention and treatment of syphilis is needed in clinical medicine around the world.

Historical syphilis infection also has been of great interest to paleopathologists over the past several decades. Venereal syphilis was a devastating disease, one of the most feared in human history [II]. In fact, it was so severe and rapidly transmitted, that it made a very strong impression on the people at the time of its initial emergence. In particular, as the appearance of syphilis occurred nearly at the same time as Columbus and his men returned from 
the New World, the idea that these two historical events were closely related to each other has long been popularly accepted [I2]. However, new arguments against this allegation having been made $\left[\mathrm{I}_{3}, \mathrm{I}_{4}\right]$, the origin of syphilis came to be hotly disputed, which debate is still ongoing among paleopathologists and historians of medicine.

Interest in venereal syphilis in East Asia is similar to that in other countries. Since the disease shows serious signs and symptoms that were rarely identified in the region, it has attracted the attention of contemporary doctors and the general public from the time of its first appearance. Since the early zoth century, the history of syphilis has been well studied in East Asian countries such as Japan. However, the volume of research on syphilis in East Asia is far smaller than that on other continents [ $[5]$. Especially in Korea, its history has been only scantily studied to date. This review summarizes the findings and achievements of medical history and paleopathological research reported to date, which information will prove valuable to future related research in South Korea and elsewhere.

\section{The Dispute on the Origin of Syphilis}

Syphilis first appeared in the $\mathrm{I}^{\text {th }}$ century $[\mathrm{I} 6, \mathrm{I} 7]$. This new STD was called by different names such as French disease (pox), Neapolitan disease, Spanish disease, the great pox, and so on [17]. The new term 'Morbus venerus' (venereal disease) was coined in 1527 by Jacques de Bethencourt, and, finally, 'syphilis' in 1530 by Girolamo Fracastoro [I7]. When syphilis first appeared in Europe, the signs and symptoms were very different from the syphilis of today. It was a disease of severe virulence that inflicted very high mortality rates $[3,17]$. As time passed, however, its virulence weakened, its lethality remarkably lessened, and finally, it came to exhibit symptoms almost identical to those seen today $[\mathrm{I} 7]$.

Regarding the origin of syphilis, there has been a very old claim that it was closely related to Columbus' discovery of the New World. In this 'Columbian hypothesis,' the seamen joining in Columbus' expedition to the New World brought the syphilis pathogen back to Europe, which then spread more widely, eventually covering the entire world. From the first time this claim was made, it has continued to be supported by many scholars as the most reliable hypothesis [I2, I8]. Briefly, Rodrigo Ruiz Diaz de Isla and Gonzalo Fernandez de Oviedo chronicled the first outbreak of a syphilis epidemic in I493, specifically in Barcelona after Columbus and his men's return 
from Haiti. In his book (published in 1539), Ruiz Diaz de Isla, a Barcelona physician who had treated Columbus' men, also stated about the illness that it was unknown disease, so far not seen and never described [12, 18-20].

Significantly, this newly emerging disease reappeared during the war (I494-I 498) conducted by the French King Charles VIII against the Kingdom of Naples. An outbreak occurred in the French army that was besieging Naples in I495 [21, 22]. When Charles VIII's army retreated back home, many soldiers were already infected by and seriously suffering from this disease [I7]. Moreover, as the war had been prosecuted mainly by the employment of mercenaries from various countries, the disease spread rapidly all over Europe soon after those soldiers returned to their home countries [17, 23, 24]. Thereby, the disease spread to France, Switzerland and Germany in I495, Britain and Scotland in I497, and the Scandinavian countries, Hungary, Greece, Poland and Russia in 5000 . By 1520, it also had spread to Africa, the Near East, East Asia, and Oceania [17]. According to supporters of this theory, this disease, which manifested as a dramatic onset followed by rapid spread, originated from the New World [12, 20].

However, this theory has been seriously challenged by other researchers. A JAMA editorial for the 1935 issue [25] stated that the syphilis originally present in the Old World was not recognized as a separate, independent disease, but for many years was confused with other illnesses such as leprosy. In 1934, Richmond Cranston Holcomb [13, I4] likewise proposed that syphilis might have existed in the Old World even before 1493 (the Pre-Columbian hypothesis). In 1974, two researchers [26] made similar claims. According to this hypothesis, Columbus' expedition to and return from the New World was coincidental with a sudden spike in syphilis virulence, which disease was mistakenly identified as a new, New World-origin disease [17]. This argument is appealing in that it can explain why syphilis-like signs have been occasionally found in bones unearthed at Old World sites dated pre-I493 [I2, $20,27]$. According to this theory, the syphilis was actually present in the Old World even before the I490s [28, 29].

However, objections to this hypothesis have been made as well. After reviewing the previous paleopathological reports, Harper et al. argued that, with respect to the diagnostic criteria, the certainty of diagnosis and the accuracy and reliability of archaeological dating, there was no single case of an Old-World skeleton that could indisputably support the pre-Columbian hypothesis, whereas there were abundant confirmed pre-Columbian cases 
[12]. This counter-argument is supported by a phylogenetic analysis based on 26 geographically disparate Treponema strains, which data showed that those venereal syphilis strains were not so old, but had originated recently from yaws strains in South America [r]. Baker and Armelagos [20], moreover, claimed that a treponematosis spread to Europe was non-venereal, and that when pathogenic Treponema was introduced from the New World to Europe, the environment of the latter induced its evolution into venereal form [20]. All of these analyses and reports support the original, Columbian hypothesis.

Although these two hypotheses (Columbian and Pre-Columbian) are the most influential nowadays, some researchers, contrarily, have argued that all treponematoses are caused by the same species of which syphilis is one variant, and that specific diseases can be differentiated only by differences in social and natural environments (the Unitarian hypothesis) [30, 3I]. They speculated that in the latter half of the 15 th century, venereal syphilis emerged from the existing non-venereal Treponema as the result of the environmental change represented by Europe [I2]. Although this hypothesis initially attracted researchers' attention, its significance has been greatly reduced as recent studies have re-confirmed that the species responsible for trepanematoses are genetically distinct from each other [I, 23, 32-34].

\section{The Emergence of Syphilis in East Asia}

On a global scale, the origin of syphilis is a subject of great interest for paleopathologists. However, in East Asia, uniquely, there has been little controversy. Researchers generally have agreed that venereal syphilis originated from the outside, based on the compelling fact that all of the extant documentation of Korea, Japan, and China indicate this.

According to these historical records, syphilis initially was spread to India by Vasco Da Gama's expedition of 1498 [4]. Next, it spread further to Guangdong (Canton) province of China in 1505 , where the disease was called 'Canton sores' or 'Canton rash' (kuang chuang) or 'plum-blossom sores' (yangmei chuang) [7]. Chinese officials at that time were certain that the disease had originated from the outside world. In I632, Chén Sì Chéng described the new disease in his book (Méi Chuāng Mì Lù) as follows: "I could not find any similar diseases in the detailed reading of the extant medical literatures. Considering its origin, it began in the Ling nan area (including Guangdong, Guangxi and Hainan) and spread throughout the country." 
Paleopathologists in Japan presented a hypothesis that sy philis was transmitted from the east coast of China (possibly Gwangdong) to Japan [35, 36]. In 1512, the first outbreak of syphilis, in Gekkai-roku, was reported by Shukei Takeda, a medical doctor at Kyoto, who described Kansai district patients manifesting typical signs of syphilis. The next year (1513), a syphilis epidemic was recorded in Myohoji-ki, a Buddhist temple's record [35, 36]. Interestingly, this means that within a year, syphilis epidemics were reported for two different, far distant places in Japan. Taking these two reports into consideration, it seems that syphilis was introduced into Japan in 1512-1513 at the latest and that it spread very fast thereafter [36].

As for Korea, Yi Soo-Kwang (1563-1628), a famous Korean scholar of the early Joseon period (the full period: 1392-I9IO CE), wrote in his book Jibong yuseol the following: "Considering the medical literature of our country, Cheonpochang is a disease that originated from China between 1506 and I52I. China did not have this kind of disease in the past. It must have been transmitted from the western world." In Sallim gyeongje, a book written by Hong Man-seon (1643-1715), the signs and symptoms of Cheonpochang were described as follows: "It is transmitted by sexual intercourse. Erosion occurs in the nose and eyes. Genitalia are also damaged. Severe pains occur in muscle and bone. It is not much different from leprosy. The skin sometimes bursts. Nose and mouth collapse. The patient eventually dies." As judged by these symptoms, the disease called Cheonpochang is highly likely to have been venereal syphilis. Koreans at that time knew that there were no syphilis-like diseases in the country before, at the latest, 1506 .

How could syphilis in East Asia be so clearly recognized as having originated from the outside world? This level of assurance might have been due to a well-established tradition of meticulous record-keeping in the relevant countries at that time. Another factor we must note is that non-venereal trepanematoses (pinta, yaws, and bejel), easily confused with venereal syphilis, were very rare in East Asia. These facts clearly made the Korean people at that time well aware that the newly emerging disease was an unusual one that had not been seen before. The historical studies to date clearly show that the first East Asian country in which syphilis was introduced was China, possibly through maritime trade, and that subsequently the disease spread very rapidly to Korea and Japan. At least by the early i6th century, syphilis must have been known to the people of East Asia. 


\section{Syphilis InFeCtion From the $16^{\text {TH }}{ }^{\text {TO }} 19^{\text {TH }}$ Centuries}

It is still unclear what the situation of syphilis in East Asia was from the I6th to Igth centuries, the period between the first introduction of the disease and the beginning of modernization. In the case of Korea, although a tremendous amount of documentation was accumulated during the Joseon period, it is very difficult for historians to find concrete facts about STDs, especially with regard to syphilis, in the records.

Nonetheless, we were able to find a good description of syphilis infection in a Joseon diary (Bubuk ilgi). In 1644-1646, Park Chui-mun (1617-1690) was stationed on the border area with Manchuria as a military officer. In his diary, he thoroughly documented the details of traveling from his hometown to the service area, his life on the border for a year, and an itinerary for his return back home. Among the everyday life described in the diary, the most relevant information to our research is a thorough record of his and others' sexual affairs with women [37].

In general, when military officers of the Joseon Dynasty served on the border area, they usually did so alone while their wives and other family members remained home. While traveling from home to their posts, they stayed at public or private accommodations. There, sexual liaisons with prostitutes sometimes occurred [37]. Also, at officers' military ports and forts at the border, female servants were assigned to them. The servants' job was officially limited to housework, but they sometimes had affairs with the officers as well [37]. As there were few brothels or red-light districts at that time, these types of contact with socially disadvantaged people such as gisaeng (Korean geisha), female servants, or prostitutes (in the accommodations etc.) were the easiest ways to get in touch with women. In Park Chui-mun's diary, incidences of sexual affairs are clearly and frankly depicted as summarized in Table I.

TABLE I. The list of females from a diary, who had relationships with males

\begin{tabular}{ccc} 
Date & Names & Social status of female \\
\hline Dec II, I644 & Tongjin & Female servant \\
Dec I5, I644 & Buni & Female servant \\
Dec I6, I644 & Chunil & Jutang \\
& Maehwa & Jutang \\
Dec I7, I644 & Okchun & Jutang \\
Dec 22, I644 & Hyanghwan & Jutang
\end{tabular}




\begin{tabular}{|c|c|c|}
\hline Date & Names & Social status of female \\
\hline \multirow[t]{2}{*}{ Dec 26, I644 } & Yehyun & Jutang \\
\hline & Doseon & Jutang \\
\hline \multirow{4}{*}{$\begin{array}{c}\text { Dec 30, I644 } \\
\text { Jan 2, I645 }\end{array}$} & Yeonhyang** & Gisaeng ${ }^{\mathrm{b}}$ \\
\hline & Geonligae & Gisaeng \\
\hline & Daehyang & Gisaeng \\
\hline & Makgae & Gisaeng \\
\hline Jan $23, \mathrm{I} 645$ & Okhwan** & Female servant \\
\hline \multirow[t]{2}{*}{ Feb 5, ${ }^{6} 6_{45}$} & Yeje & Daughter of servant \\
\hline & Hoedeok*** & Female servant \\
\hline \multirow[t]{2}{*}{ Feb 6, I645 } & Okmaehyang & $?$ \\
\hline & Taehyang & Jutang \\
\hline Feb II, I645 & Oksun & Gisaeng \\
\hline $\mathrm{Feb}_{13}, \mathrm{I}_{45}$ & Yuldeok & Female servant \\
\hline \multirow[t]{4}{*}{ Feb I4, I645 } & Hyangchun & Daughter of servant \\
\hline & Okseon & $?$ \\
\hline & Hwasun & $?$ \\
\hline & Hyanggae & Gisaeng \\
\hline Feb I7, I645 & Weolmae & Gisaeng \\
\hline Feb I9, I645 & Hoedeok ${ }^{* * *}$ & Gisaeng \\
\hline Feb 23, I645 & Nojong & Female servant \\
\hline May II, I645 & Seolmae & \\
\hline May I5, I645 & Seolmae & \\
\hline Jun 28, I645 & Sunjin & Gisaeng \\
\hline Jun $2, \mathrm{I}^{6} 45^{*}$ & Seolmae & \\
\hline Jun I9, $1645^{*}$ & Seolmae & \\
\hline Aug I3, I645 & Ok-yi & Gisaeng \\
\hline Aug I4, I645 & Hyanga & \\
\hline Aug 15, I645 & Gyeokhyang & Gisaeng \\
\hline Oct 2I, I645 & Okmae & Gisaeng \\
\hline Oct 23,1645 & Aeseng & Female servant \\
\hline \multirow[t]{2}{*}{ Oct 25,1645} & Hyangseng & Gisaeng \\
\hline & Cheonsi & Gisaeng \\
\hline
\end{tabular}

\footnotetext{
${ }^{\mathrm{a}}$ Jutang and ${ }^{\mathrm{b}}$ Gisaeng, different terms for Korean geisha. * Leap month of lunar calendar; ** Infected by Dangchang; *** Different persons; The table is based on Bak [38] and Woo $[37,39]$.
}

Interestingly, according to the diary, Park met with two different females (Yeonhyang and Okhwan) infected with serious STD (Dangchang) (Table I). As there were 36 women who appeared as sexual partners of the men noted in the diary, at least $5.6 \%$ of them, therefore, were infected by Dangchang. The relevant details on the Dangchang-infected women are described in the diary as follows [39]. 
[CASE I]

- Dec 30, I644: I slept with Yeonhyang (Gisaeng)

- Jan I2, I645: I went to the Gisaeng (Geonligae)'s house and slept with her. (After then) she asked me, "My lord, did you ever sleep with Yeonhyang in the neighborhood?" When I answered that I had, she sat up without saying a word and started to weep. Her mother and brother, surprised by the sound of her weeping, came and asked why. She replied, "My lord slept with Yeonhyang yesterday night." Then, her mother also started to weep. I asked why, then they answered that she (Yeonhyang) had a Dangchang. Everyone was greatly discouraged and worried all the night.

[CAse 2]

- Jan 23, I645: (He stayed at school) When I expressed my hope to sleep with the female servant at the school, the master strictly prohibited it. As her appearance was so beautiful, Jang Joon-min surreptitiously undertook to sleep with her. In the morning of the next day, the master scolded us, "She is a beautiful woman. But she also has a Dangchang. Why didn't you listen to my word? Poor friends!"

We wonder if the Dangchang referred to what was actually syphilis. During the Joseon period, according to medical historians, multiple terms were simultaneously used for syphilis. These include Cheonpochang and Yangmaechang as well as Dangchang [40]. In fact, the term Dangchang was used not only in Korea but also in Japan as a term to refer to syphilis. If we accept this view that Dangchang is syphilis, the just examined military officer's mid-I7th century diary clearly shows that syphilis, after its initial transmission from China, had spread in Joseon society to such an extent that this one officer occasionally met syphilis-infected patients on his travels. However, estimation of the actual syphilis infection rate in Joseon society based on historical documents alone remains difficult.

Meanwhile, in Japan, clinical descriptions of syphilis appear frequently in the historical literature on the Edo period (I603-I868) [35]. A Western missionary who visited Japan in the late I6th century noted the STDs prevalence among the Japanese people [36]. Although there are no accurate official statistics on venereal syphilis during the Edo period, contemporary doctors claimed that more than half of the population might have been infected by syphilis [36]. A more detailed record was reported by Ryojun Matsumoto (I832-1907), the physician serving the last Shogun of Japan. According to his 
estimate, $95 \%$ of lower-class people were likely to be suffering from syphilis [35]. Although its initial introduction was chronologically almost identical to that in Korea, syphilis infection in Japan seems to have spread much more vigorously from the i6th to igth centuries.

This is understandable in that, unlike Korea, large brothels and red-light districts had been established in the large cities of Edo-period Japan, where city people engaged easily with prostitutes [36]. According to Suzuki [35], higher incidences of cranial syphilis were identified in Edo-period skeletons found in the downtown district where the unlicensed red-light district was located.

However, the records of diseases in the historical literature are difficult to analyze, especially due to inaccurate diagnoses stemming from ambiguous disease classifications and records. Thus, the authenticity of some historical cases diagnosed as venereal syphilis is in doubt. In this regard, the knowledge acquired by historical research needs to be re-confirmed by paleopathological investigation.

\section{Paleopathological Study ON SKeletons}

Syphilis often leaves remarkable traces on bones after it has been left to progress without effective treatment [I]. Venereal syphilis involves multiple bones such as the tibia, skull, sternum, clavicle, vertebrae, femur, fibula, humerus, ulna and radius. Of them, the most characteristic signs appear on the skull, commonly affecting the parietal, frontal and facial (nasal-palatal) bones. Gumma is frequently identified in tertiary syphilis as the foci of necrotic bone and the surrounding sclerotic rim. The most common result of gummatous lesions is caries sicca of the skull. Non-gummatous lesions such as periostitis, osteitis, and osteoperostitis also are indicative of venereal syphilis [4]. Thus, insight into syphilis infection onsets and patterns in history can be obtained by paleopathological analysis of ancient skeletons obtained from archaeological sites.

There have been notable paleopathological achievements in the study of ancient syphilis in Japan. As early as I894, bone scars were identified in the parietal and frontal bones of the modern Ainu people as possible signs of syphilis [4I]. Subsequent studies on pre-I6th century skeletons in Japan, however, found no osteological signs indicative of syphilis [36, 42]. In Japan, the earliest evidence of venereal syphilis ( 3 out of 23 specimens; $13.0 \%$ ) was obtained from skeletons dating to the late Muromachi period (I333-I573) 
[43-48]. As for the following Edo period (I603-1868), paleopathological studies have confirmed that many skeletonized individuals (50/926) had been infected with syphilis, thus revealing that the syphilis infection rate was very high indeed among the Edo Japanese $[15,35,36]$.

Meanwhile, in the case of Korea, research on ancient skeletons was relatively less active than in Japan; paleopathological studies on syphilis properly began only after the first decade of the $2 \mathrm{I}^{\text {st }}$ century. Accordingly, there is as yet little data to supplement historical research. However, recent attempts to analyze the osteological signs of syphilis remnant from i6th to Igth century Joseon skeletons are worth noting. In a series of paleopatholgical studies on Joseon skeletons conducted at Seoul National University College of Medicine (n=I60: I04 cases previously reported in [49]; 56 cases additionally examined in 20I7), no definite signs of syphilis (e.g. caries sicca) were found in the cranial and postcranial skeletons other than a few suspicious signs. Although signs of periostitis were sometimes found in the bones, we could not confirm them as syphilis-specific. Considering these results, we conjecture that osteological signs of syphilis are very rare in Joseon skeletons compared with those in Edo samples.

Did the Joseon people suffer less from syphilis than we had thought, then? According to the historical literature, syphilis must have existed among Joseon Koreans at least since the 16 th century. We tried to explain this discrepancy, by reconsidering the historical records and paleopathological findings. First, it is possible that the prevalence of syphilis infection in Joseon society might actually have been very low. The infection rate from the r6th to rgth centuries was so low that syphilis cases are not easy to find among Joseon skeletons. If this is the case, some historical records on syphilis, though likely not all, might have been the outcomes of misdiagnosis. In fact, for many centuries in medical history, various types of STDs have been erroneously regarded as a single disease entity. Gonorrhea, chancroid, and syphilis could not be differentiated as separate, distinct diseases before Philippe Ricord managed to show that gonorrhea and syphilis were distinct in $1838[3,17,21,50,5 \mathrm{I}]$.

Another explanation is that the relative paucity of instances of syphilis among Joseon specimens is due to selection bias. Almost all of the skeletons that we have examined came from Joseon graves of unique structure (Hoegwakmyo), which are representative of the burials commonly used for high-class people of the period. Interestingly, in studies on a Japanese skeletal 
series, those of the well-educated, strongly self-disciplined, high-class samurai group had fewer syphilis cases than did less-educated, humbler people $[35,36]$. The patterns of Japanese syphilis infection that parallel social status might also be applicable to Joseon society.

\section{The SitUATION ON THE EVE OF THE $20^{\text {TH }}$ CENTURY}

As we have seen, it is not clear how seriously syphilis infected the Joseon people over the course of the hundreds of years after its initial entry into Korea. It is difficult to find evidence in the related historical literature [52], other than the accounts in the officer's diary noted above. However, in I886, statistics on the Joseon people's diseases as diagnosed by modern clinical medicine were presented for the first time by Horace Newton Allen (18581932), an American missionary and medical doctor who had been dispatched to Korea. During his stay in the country, he was in charge of the Korean Government Hospital in Seoul at the request of the Joseon King. In his first year running the hospital (I886), he prepared a report on the patients who had come there. We noted the remarkably high ratio of syphilis infection among the patients in his report. In brief, of the patients ( $\mathrm{n}=\mathrm{IO} 460$ ) who visited the Korean Government Hospital in Seoul, the number with syphilis and sequelae was as high as II40, or Io.9\% (Table 2) $[52,53]$.

TABLE 2. The statistics of patients admitted to Korean Government Hospital in a year (I886)

Syphilis-Related Diseases

Number of Patients

\begin{tabular}{|c|c|c|}
\hline Syphilis & & 760 \\
\hline \multirow{7}{*}{ 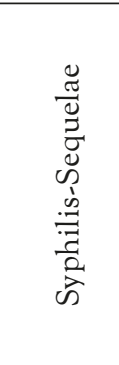 } & Syphilitic Gumma Anus & 89 \\
\hline & Syphilitic Periostitis & 96 \\
\hline & Syphilitic Rupia & 44 \\
\hline & Syphilitic Tubercle Face & $2 \mathrm{I}$ \\
\hline & Syphilitic Ulcers Body and Legs & 60 \\
\hline & Syphilis and Leprosy & $5^{2}$ \\
\hline & Syphilitic Ulcer Throat & $\mathrm{I} 8$ \\
\hline \multirow{3}{*}{ 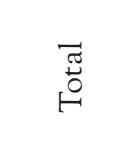 } & Syphilis Total & II 40 \\
\hline & Genito-Urinary Diseases Total & 1902 \\
\hline & Patients Total & 10406 \\
\hline
\end{tabular}

This report is especially significant when compared with the statistics of neighboring countries for almost the same period. For instance, in a study 
conducted at five hospitals in Northern Manchuria (I9I3-I925), the ratio of syphilis patients ranged from 2.9 to $8.1 \%$, an average $6.4 \%$ of total patients [50]. According to the statistics for dermato-urological patients in Meijiperiod Japan, the number of patients with syphilis was 23I (9.07\%) of 2547 (total outpatients) [35]. This means that the proportion of syphilis patients who visited a Korean Government Hospital in 1886 was never lower than in other countries that had undergone modernization and urbanization in the early 20 th century.

How did Korea come to suffer such a high infection rate of syphilis in I886? There are some possible explanations for this abrupt transition. As mentioned earlier, the Joseon skeletons used in our paleopathological study might not adequately reflect the entire Korean population at that time. Assuming this, the actual syphilis infection rate from the $16^{\text {th }}$ to $19^{\text {th }}$ centuries might have been even higher than estimated by paleopathologists. Next, we could not rule out that there might have been some errors in Allen's diagnosis of syphilis; or, patient group who visited the Korean Government Hospital might have been affected by a selection bias.

Having considered all of these possibilities, however, there are fewer reasons for us to question or deny the credibility of Allen's report on syphilis infection in 1886 [52]. As 300 years had already passed since the first introduction of syphilis in the early I6th century, there is nothing strange about the notion that syphilis was widespread among the Joseon people by 1886 . If this is true, Allen's report is invaluable in confirming that the syphilis infection rate among the Joseon people had already reached a high level before the colonization period (I9IO-I945), which level was not so different from those of China and Japan.

\section{THE TURNING POINT OF SYPHILIS INFECTION: COLONIZATION}

After the Sino-Japanese War (I894-I895), Korea was gradually colonized by Japan. As colonization progressed, a number of Japanese colonists came to Korea. In the villages where they lived, large-scale brothels and red-light districts were opened, thus inaugurating a new type of prostitution and greatly facilitating such transactions thereby [40].

From the Edo period, the red-light district had been the typical mode of prostitution in Japan. Licensed (Yoshiwara) and unlicensed red-light districts competed with each other for clients in urban areas $[54,55]$. The problem of this type of prostitution was its potential as a vehicle for the spread of STDs. 
Prostitutes in the red-light districts were obliged to do work with little rest while suffering poor nutrition, thus weakening them and rendering them even more vulnerable to infection by various kinds of STDs [56]. The incidence of syphilis among Japanese prostitutes reached as high as $80 \%$ or more in $1867[36,57]$. Although the situation has improved by enhanced hygiene and new drugs, the incidence of syphilis was still about $70 \%$ among licensed prostitutes $[36,58]$.

In colonial Korea, to which the organized business of prostitution was transplanted from Japan, the prevalence of STDs among prostitutes was similar. According to the Japanese Resident-General of Korea's inspection in 1906, the ratio of positives among prostitutes reached as high as $46 \%$ [40]. Making sex easy to buy meant that more people could be infected by syphilis more easily than before. Medical historians agree that Korean society became more susceptible to large-scale syphilis infections via red-light districts during the colonial period [40].

\section{Conclusion}

The extant documentation of Korea, Japan, and China all indicates that syphilis originated from the outside world (i.e., from India, via Europe); obviously therefore, the Pre-Columbian hypothesis cannot be applied to East Asia. According to the historical and paleopathological information available so far, in the early i6th century syphilis spread from China to Japan, almost as quickly as it had arrived in China. In Joseon society, the syphilis infection rate was not as high as in those two neighboring countries. The slow spread pattern of STDs during the Joseon period might have been due to the lack of large-scale brothels in Korea. However, by the end of the $19^{\text {th }}$ century, this situation had changed. According to an 1886 medical report, syphilis already accounted for a significant proportion (ro.9\%) of patients visiting the hospital. Soon thereafter, in the process of Japanese imperial colonization, red-light districts were transplanted from Japan. This completely changed the pattern of, and accelerated, syphilis infection in Korea from then on. In this review, we have shown how syphilis was introduced to Korea and by what processes it was transmitted among Koreans until the $20^{\text {th }}$ century. Until corroborating paleopathological evidence is available however, our conclusions will remain tentative. 


\section{REFERENCES}

[1] K. N. Harper, P. S. Ocampo, B. M. Steiner et al., "On the origin of the treponematoses: a phylogenetic approach," PLOS Neglected Tropical Diseases, vol. 2, no. 1, e148, 2008.

[2] F. L. de Melo, J. C. de Mello, A. M. Fraga, K. Nunes, and S. Eggers, "Syphilis at the crossroad of phylogenetics and paleopathology," PLOS Neglected Tropical Diseases, vol. 4, no. 1, e575, 2010.

[3] M. Tampa, I. Sarbu, C. Matei, V. Benea, and S. R. Georgescu, "Brief History of Syphilis," Journal of Medicine and Life, vol. 7, no. 1, pp. 4-10, 2014.

[4] A. C. Aufderheide and C. Rodriguez-Martin, The Cambridge Encyclopedia of Human Paleopathology, Cambridge University Press. New York. 1998.

[5] K. A. Fenton, R. Breban, R. Vardavas et al., "Infectious syphilis in high-income settings in the 21st century," Lancet Infectious Diseases, vol. 8, no. 4, pp. 244-253, 2008.

[6] M. S. Cohen, G. E. Henderson, P. Aiello, and H. Zheng, "Successful eradication of sexually transmitted diseases in the People's Republic of China: implications for the 21st century," The Journal Infectious Diseases, vol. 174, Suppl 2, S223-229, 1996.

[7] X. S. Chen, Y. P. Yin, Q. Q. Wang, and B. X. Wang, "Historical perspective of syphilis in the past 60 years in China: eliminated, forgotten, on the return," Chinese Medical Journal, vol. 126, no. 14, pp. 2774-2779, 2013.

[8] J. Sun, Z. Meng, K. Wu et al., "Tracing the origin of Treponema pallidum in China using next-generation sequencing," Oncotarget, vol. 7, no. 28, pp. 4290442918, 2016.

[9] A. C. Gerbase, J. T. Rowley, D. H. Heymann, S. F. Berkley, and P. Piot, "Global prevalence and incidence estimates of selected curable STDs," Sexually Transmitted Infections, vol. 74, Suppl 1, S12-16, 1998.

[10] D. Walker and G. Walker, "Syphilis: a forgotten priority," PLOS Medicine, vol. 3, no. 4, e204, 2006.

[11] N. Arora, V. J. Schuenemann, G. Jäger et al., "Origin of modern syphilis and emergence of a pandemic Treponema pallidum cluster," Nature Microbiology, vol. 2, pp. 16245, 2016.

[12] K. N. Harper, M. K. Zuckerman, M. L. Harper, J. D. Kingston, and G. J. Armelagos, "The origin and antiquity of syphilis revisited: an appraisal of old world pre-Columbian evidence for treponemal infection," Yearbook of Physical Anthropology, vol. 54, pp. 99-133, 2011.

[13] R. C. Holcomb, "Christopher Columbus and the American origin of syphilis," United States Naval Medical Bulletin, vol. 32, pp. 401-430, 1934. 
[14] R. C. Holcomb, "The antiquity of syphilis," Medical Life, vol. 42, pp. 275-325, 1935.

[15] P. Giannakopoulou and T. Suzuki, "History of Paleopathology in Japan," in The Global History of Paleopathology: Pioneers and Prospects, J. E. Buikstra and C. A. Roberts, Eds. Oxford University Press. Oxford, UK, 2012.

[16] R. H. Major, Classic Descriptions of Disease, Springfield, USA: Charles C Thomas, 1932.

[17] J. Frith, "Syphilis - Its early history and Treatment until Penicillin and the Debate on its Origins," Journal of Military and Veterans' Health, vol. 20, no. 4, pp. 49-58, 2012.

[18] A. Crosby, "The early history of syphilis: a reappraisal." American Anthropologist, vol. 71, pp. 218-227, 1969.

[19] W. Schreiber and F. K. Mathys, Infectio: Infectious Diseases in the History of Medicine. Roche, Ed. Hoffmann, 1987.

[20] B. Baker and G. J. Armelagos, "The origin and antiquity of syphilis: Paleopathological diagnosis and interpretation," Current Anthropology, vol. 29, pp. 703-738, 1988.

[21] E. H. Ackerknecht, A Short History of Medicine, Revised edition, John Hopkins University Press, Baltimore, 1982.

[22] A. Karlen, Man and Microbes, GP Putnam's Sons, New York, 1995.

[23] C. Quétel, “Compiler,” in History of Syphilis. Polity, Cambridge, UK, 1992.

[24] L. J. McGough, "Syphilis in History: A Response to 2 Articles," Clinical Infectious Diseases, vol. 41, no. 4, pp. 573-575, 2005.

[25] JAMA, "The origin of syphilis," JAMA, vol. 104, no. 24, pp. 2188-2189, 1935.

[26] J. E. Lobdell and D. Owsley, "The origin of syphilis," The Journal of Sex Research, vol. 10, no. 1, pp. 76-79, 1974.

[27] B. Lopez, J. M. Lopez-Garcia, S. Costilla et al., "Treponemal disease in the Old World? Integrated palaeopathological assessment of a 9th-11th century skeleton from north-central Spain," Anthropological Science, vol. 125, no. 2, pp. 101 $114,2017$.

[28] C. Hackett, "On the origin of the human treponematoses (pinta, yaws, endemic syphilis and venereal syphilis)," Bulletin of World Health Organization, vol. 29, pp. 7-41, 1963.

[29] C. Hackett, "The human treponematoses," in Diseases in antiquity, D. Brothwell, A. Sandison, Eds, Thomans, Springfield, IL, pp. 152-169, 1967.

[30] E. Hudson, "Treponematosis and anthropology," Annals of Internal Medicine, vol. 58, pp. 1037-1048, 1963. 
[31] E. Hudson, "Treponematosis and man's social evolution," American Anthropologists, vol. 67, pp. 885-901, 1965.

[32] A. Centurion-Lara, B. J. Molini, C. Godornes et al., "Molecular differentiation of Treponema pallidum subspecies," Journal of Clinical Microbiology, vol. 44, no. 9, pp. 3377-3380, 2006.

[33] R. R. Gray, C. J. Mulligan, B. J. Molini et al., "Molecular evolution of the tprC, $\mathrm{D}, \mathrm{I}, \mathrm{K}, \mathrm{G}$, and J genes in the pathogenic genus Treponema," Molecular Biology and Evolution, vol. 23, no. 11, pp. 2220-2233, 2006.

[34] C. J. Mulligan, S. J. Norris, and S. A. Lukehart, "Molecular studies in Treponema pallidum evolution: toward clarity?," PLOS Neglected Tropical Diseases, vol. 2, no. 1, e184, 2008.

[35] T. Suzuki, Palaeopathological and palaeoepidemiological study of osseous syphilis in skulls of the Edo Period (Bulletin No.23), The University Museum, The University of Tokyo, Tokyo, 1984.

[36] T. Suzuki, History of Japanese old pathology seen from bone talks about, Kodansha academic library, Japan, 2010.

[37] I-S. Woo, "Barrack lives of Chulsinkungwan at the border line in the 17th century based on Bubukilgi," The Journal of Korean History, vol. 96, pp. 35-73, 1997.

[38] D-W. Bak, "Sexual awareness observed in diaries in Joseon period-visible sex, hidden sex-," Journal of Korean Literature in Chinese, vol. 39, pp. 63-90, 2014.

[39] I-S. Woo, Bubukilgi (Translation). Ulsan Museum, Ulsan, South Korea, 2012.

[40] K. H. Shin, "Gaehang Ihu Wa Daehan Jaeguk Gi,” in Hanguk Jeonyeombyeongsa, The Korean Society of Infectious Diseases, South Korea, 2009.

[41] Y.Koganei, "Beiträge zur physischen Anthropologie der Aino.I.Untersuchungen am Skelet; II. Untersuchungen am Lebenden," in Mittheilungen aus der Medicinischen Facultät der Keiserlich-Japanischen Universität, Tokyo University, Tokyo, 1894.

[42] T. Suzuki, "Paleopathological study on infectious diseases in Japan," Zagreb Paleopathology Symposium, pp. 128-139, 1988.

[43] H. Suzuki, Human skeletal remains of the ancient Japanese population, pp. 223, Iwanami-Shoten, Tokyo, 1963 (In Japanese).

[44] Y. Fujikawa, "On the origin of syphilis in Asia," Journal of Dermatology and Urology, vol. 2, pp. 202-219, 1902 (In Japanese).

[45] Y. Fujikawa, The History of Medicine in Japan, Keiseisha, Tokyo, 1904 (In Japanese), (Summarized in German, Y. Fujikawa, Geschichte der Medizin in Japan. Herausgegeben vom Kaiselich-Japanishen Unterrichtsministerium, Tokyo, 1911).

[46] Y. Fujikawa, The History of Diseases in Japan, Nipponsha, Tokyo, 1912 (In Japanese). 
[47] K. Dohi, "Recent development of venerology," Journal of Dermatology and Urology, vol. 2, pp. 173-201, 1902 (In Japanese).

[48] K. Dohi, The World History of Syphilis, Keiseisha, Tokyo, 1921 (In Japanese).

[49] Y. S. Kim, D. K. Kim, C. S. Oh et al., "Evidence of Periostitis in Joseon Dynasty Skeletons," Korean Journal of Physical Anthropology, vol. 26, no. 2, pp. 81-90, 2013.

[50] K. H. Shin, Dong Asia Euihakeui Jaebalgyeon: Jilbyeongeuni Sahoesa, Sallym Chulpansa, Paju, 2006.

[51] J. Forrai, "History of Different Therapeutics of Venereal Disease Before the Discovery of Penicillin," Syphilis Recognition, Description and Diagnosis, N. S. Sato, Ed., InTech, Rijeka, Croatia, 2011.

[52] S. I. Hwang, Geundae euiryo eui punggyeong, Purun Yeoksa, Seoul, South Korea, 2013.

[53] I. S. Yeo, Allen Eui Euiryo Bogoseo. Yeoksa Gonggan, Seoul, South Korea, 2016.

[54] Y. Nishiyama, Yujo (the prostitutes in the Edo period), pp. 275, Kondo Shuppan, Tokyo, 1979 (in Japanese).

[55] K. Higuchi, Sei (Historical problems on the sexual morality and education in Japan), The People's History in Japan, no. 4, pp. 240, Kodansha, Tokyo, 1980 (in Japanese).

[56] Y. Miyamoto, "Diseases of the Yujo in Edo period," in Yujo, M. Nishikawa, Ed., pp. 168-169, Kondo-Shuppan, Tokyo, 1979 (in Japanese).

[57] Y. Kamimura, History of the gay quarters in Japan, pp. 615, Shunyo-do, Tokyo, 1929 (in Japanese) (republished in 1982, Fujimori Shoten, Tokyo).

[58] S. Nakano, M. Suematsu, and S. Omori, "On the experimental reports of use of Wassermann's reaction to diagnose syphilis among prostitutes," Journal of Dermatology and Urology, vol. 10, pp. 818-820, 1910 (in Japanese).

\section{SAŽETAK}

Od kraja 15. stoljeća sifilis se počeo širiti svijetom kao ozbiljna prijetnja javnom zdravstvu. Venerički sifilis glavna je istraživačka tema ne samo u kliničkoj medicini već i u paleopatologiji, pogotovo zato što je to bolest upitnog podrijetla te visoke prevalencije sve do otkrića antibiotika. U povijesti se sifilis opsežno proučavao u Europi i Amerikama, a manje u Aziji. U ovom se pregledu, na temelju postojećih povijesnih dokumenata i raspoloživih paleopatoloških podataka, točno utvrđuje početak $i$ prati širenje veneričnog sifilisa u Koreji do kraja 19. stoljeća. Pregled pruža temeljne informacije koje će biti od velike pomoći za buduća istraživanja o sifilisu prije 2o. stoljeća u Koreji.

Ključne riječi: sifilis; dinastija Joseon; Koreja; podrijetlo; povijest; paleopatologija 